\title{
A SARS-CoV-2-járvány hatása a kórházon kívüli és belüli szívmegállásra
}

\author{
Fekete-Győr Alexandra dr. ${ }^{1}$. Kovács Enikő dr. ${ }^{2}$ \\ Kiss Boldizsár dr. ${ }^{3}$ - Zima Endre dr. ${ }^{3}$
}

\author{
${ }^{1}$ Chelsea and Westminster Hospital NHS Foundation Trust, London, Egyesült Királyság \\ ${ }^{2}$ Semmelweis Egyetem, Általános Orvostudományi Kar, Aneszteziológiai és Intenzív Terápiás Klinika, Budapest \\ ${ }^{3}$ Semmelweis Egyetem, Általános Orvostudományi Kar, Városmajori Szív- és Érgyógyászati Klinika, Budapest
}

\begin{abstract}
A koronavírus-betegség (COVID-19) okozta közvetlen mortalitáson túl, a járvány közvetett úton is hatással lehet a hirtelen szívhalálra. Egyre növekvő számú közlemény foglalkozik a járványnak a hirtelen szívhalálra kifejtett közvetett hatásával. A kijárási korlátozások és az egészségügyi rendszerek átszervezése hozzájárulhatott ahhoz, hogy a járvány alatt mind a kórházon kívüli, mind a kórházon belüli szívhalál előfordulása megemelkedett. Közegészségügyi intézkedések, mint a korlátozások és a kórházak átszervezése, megváltoztathatják az egészségügyi szolgáltatásokhoz való hozzáférést, ezért hozzájárulhattak az elmúlt évben tapasztalt emelkedett számú szívmegálláshoz. Közleményünk célja a SARS-CoV-2-járvány hirtelen szívhalálra kifejtett hatására vonatkozó, a nemzetközi irodalomban jelenleg megtalálható tanulmányok összefoglalása, melyek a kórházon kívüli szívmegállás előfordulásának háromszoros emelkedéséről számoltak be a járványt megelőző évhez képest. Általánosságban elmondható, hogy a kórházon kívüli szívmegállás a járvány ideje alatt nagyobb gyakorisággal járt nem sokkolandó ritmussal, hosszabb idő telt el a mentők kiérkezéséig, alacsonyabb volt a szemtanú által megkezdett újraélesztés, a spontán keringés visszatérésének, valamint a kórházi elbocsátásnak a gyakorisága. A járványnak a kórházon belüli szívmegállásra kifejtett hatása kevésbé vizsgált az irodalomban. Míg a hirtelen szívhalált követő mortalitás néhány kutatásban jelentős emelkedést mutatott, addig máshol nem volt különbség a járványt megelőző időszakhoz képest. A COVID-19-pandémia ideje alatt jelentősen megnövekedett kórházon kívüli és belüli szívmegállás hátterében a járványnak közvetett úton is szerepe lehet, a fertőzés közvetlen hatása mellett. A túlélési lánc megbomlását számos helyen tapasztalták, ami hozzájárulhatott a kedvezőtlen kimenetelhez. Mind a prehospitális, mind pedig a hospitális ellátás gyakorlatában bekövetkező jelentős változások magyarázhatják a világ különböző pontjain megfigyelt eltéréseket.
\end{abstract}

Orv Hetil. 2021; 162(46): 1831-1841.

Kulcsszavak: COVID-19, kórházon kívüli szívmegállás, kórházon belüli szívmegállás, kimenetel

\section{The impact of the SARS-CoV-2 pandemic on out-of-hospital and in-hospital cardiac arrest}

The direct effect of COVID-19 on mortality through acute respiratory failure is well-established. However, there are a growing number of publications suggesting that the prevalence and outcome of sudden cardiac death may also be indirectly affected by the pandemic. Public health measures, such as lockdowns and reorganisation of hospitals, can alter the access to healthcare services and therefore might have contributed to the excess number of cardiac arrests which were seen over the last year. Our aim was to review the currently available publications regarding the impact of the COVID-19 pandemic on out-of-hospital and in-hospital cardiac arrests. A recent study reported a 3-fold growth in the incidence of out-of-hospital cardiac arrests during the 2020 COVID-19 period compared to the year before. In general, the number of non-shockable rhythms increased, bystander-witnessed cases and bystander-initiated cardiopulmonary resuscitation were reduced and ambulance response times were significantly delayed during the pandemic. Return of spontaneous circulation and survival to discharge substantially decreased compared to the time before the pandemic. The difference between the rate of mortality following in-hospital cardiac arrest during and before the pandemic is controversial according to published data. The incidence of out-of-hospital and in-hospital cardiac arrests significantly increased during the pandemic compared to previous years suggesting direct effects of COVID-19 infection and indirect effects from new public health measures. The disruption of the chain of survival could have contributed to the increased mortality following out-of-hospital cardiac arrest.

Keywords: COVID-19, out-of-hospital cardiac arrest, in-hospital cardiac arrest, outcome

Fekete-Györ A, Kovács E, Kiss B, Zima E. [The impact of the SARS-CoV-2 pandemic on out-of-hospital and inhospital cardiac arrest]. Orv Hetil. 2021; 162(46): 1831-1841.

(Beérkezett: 2021. augusztus 14.; elfogadva: 2021. szeptember 10.) 


\section{Rövidítések}

ARDS = akut respirációs distressz szindróma; BLS = (basic life support) alapszintû́ újraélesztés; COVID-19 = (coronavirus disease 2019) koronavírus-betegség 2019; CPR = cardiopulmonalis resuscitatio; DNACPR $=($ do not attempt cardiopul monary resuscitation) ne végezz cardiopulmonalis resuscitatiót; ERC = (European Resuscitation Council $)$ Európai Újraélesztési Tanács; ILCOR = (International Liaison Committee on Resuscitation) Nemzetközi Újraélesztési Kapcsolattartó Bizottság; IQR = (interquartile range) interkvartilis tartomány; $\mathrm{PaO}_{2} / \mathrm{FiO}_{2}=$ artériás parciális oxigéntenzió/belégzett oxigénkoncentráció; PEA = pulzus nélküli elektromos aktivitás; ROSC $=($ return of spontaneous circulation $)$ a spontán keringés visszatérése; SARS-CoV-2 = (severe acute respiratory syndrome coronavirus 2) súlyos akut légúti tünetegyüttest okozó koronavírus-2

A súlyos akut légúti tünetegyüttest okozó koronavirus-2 (SARS-CoV-2, a koronavírus-betegségért felelős vírus) [1], melyet először Kína Hupej tartományában jelentettek 2019 decemberében [2], csaknem 196,5 millió ember megbetegedéséért és több mint 4,2 millió halálesetért felelős világszerte az Egészségügyi Világszervezet (WHO) 2021. július 30-i jelentése alapján [3]. A WHO a megbetegedést, amely az egész világon súlyos egészségügyi és gazdasági problémát jelent napjainkig, 2020. március 11 -én világjárvánnyá nyilvánította [3]. Az egészségügy világszerte jelentős mértékű megterhelés alatt áll, számos ország a megbetegedés sokadik hullámával, illetve újabb vírusvariánsokkal kényszerül szembenézni $[4,5]$.

A járványnak a prehospitális és hospitális ellátásra, valamint a népesség egészségére gyakorolt hatása a mai napig kibontakozóban van. A koronavírus-betegség (COVID-19) okozta közvetlen mortalitáson túl egyre nagyobb az aggodalom a járványnak az egészségügyi rendszerre kifejtett járulékos szocioökonómiai és pszichológiai hatása miatt [5-7]. A lezárások és kijárási korlátozások, valamint a kórházi megfertőzéstől való félelem lehet többek között az oka annak a számos országban megfigyelt jelenségnek, hogy a betegek egy része szükség esetén sem veszi igénybe a mentőszolgálatot, illetve nem jelentkezik a sürgősségi osztályokon, ami az optimális ellátás hiányához, illetve késéséhez, következményes állapotromláshoz vezethet $[4,5]$. Tovább nehezíti a helyzetet az egészségügyi rendszerek teljes átszervezése, alkalmazkodva a jelentős mértékü beteghullámhoz. Rutin kórházi beavatkozások és elektív műtétek leállításával biztosította az egészségügyi rendszer, hogy a kórházi ellátás a COVID-19-ben szenvedőkre tudjon koncentrálni, és minimalizálni tudja a stabil betegek lehetséges kontaminációját. Összességében ezek a járvány okozta indirekt hatások a népesség egészségi állapotában jelentôs mértékü kárt okozhatnak [4].

Erre példa a járvány kezdete óta megfigyelt megnőtt incidenciájú, kórházon kívüli szívmegállás is. Egy tanulmány háromszoros emelkedést talált a kórházon kívüli szívmegállás előfordulásában a járványt megelőzó évhez képest [8].

A keringésmegállás és újraélesztés túlélési lánca azon folyamatokat foglalja magában, melyek igazoltan javítják az újraélesztés kimenetelét. Részei a korai észlelés és a gyors segítséghívás, a korai, jó minőségű alapszintű újraélesztés (BLS), a defibrillálás és az adekvát postresuscitatiós kezelés. Minden láncszem egyenértékű és nélkülözhetetlen a hirtelen szívhalállal járó magas mortalitás csökkentése érdekében [9]. A pandémia a túlélési lánc megbontásával kedvezőtlen hatással lehet a betegek túlélésére. Két szisztematikus áttekintő tanulmány elemezte a járvány közvetlen és közvetett hatását a hirtelen szívhalálra nézve $[5,10]$.

A COVID-19 az esetek többségében influenzaszerű tünetekkel járó megbetegedés, a betegek egy része azonban rohamosan súlyosbodó hypoxiás légzési elégtelenség állapotába kerül, mely azonnali kezelés nélkül előbb vagy utóbb szívmegálláshoz vezet. A hypoxia szöveti szintű anaerob metabolizmusra való átállás révén laktátacidózist idéz elő, melynek következtében az endogén katecholaminok hatása kevéssé érvényesül. Az utóbbi folyamat és az oxigénhiány direkt sejthatása nem sokkolandó ritmushoz, PEA-hoz vagy asystoliához vezet. Továbbá a SARS-CoV-2-infekció által okozott érrendszeri gyulladás, myocardialis sérülés [11], thromboemboliás események [12] - melyek myocardialis infarctushoz vagy tüdőemboliához vezethetnek - mind a hirtelen szívhalál közvetlen okai lehetnek.

A gyors, rövid időablakú beavatkozást sürgető, életveszélyes kórképek - mint az akut coronaria szindróma [13] - kezelésének késése szintén szívmegálláshoz vezethet, mivel az irodalomban igazoltan ismert, hogy a legtöbb, kórházon kívüli szívmegállás hátterében myocardialis ischaemia áll [14]. Ezenkívül a hirtelen szívhalált követő túlélésre hatással lehet a fertőzéstől való félelem, következményesen az alacsonyabb arányú, szemtanú által megkezdett BLS [15], valamint a mentőszolgálat túlterheltsége [16]. Ezek többek között azok az indirekt faktorok, amelyek szerepet játszhatnak a járvány alatt megfigyelt emelkedett számú, kórházon kívüli szívmegállásban és mortalitásban [10].

Közleményünk célja a SARS-CoV-2 okozta járványnak a kórházon kívüli, illetve belüli szívhalálra kifejtett hatására vonatkozó, a nemzetközi irodalomban jelenleg megtalálható tanulmányok összefoglalása.

Elektronikus adatgyújtést végeztünk a PubMed, MedScape és EMBASE adatbázisokban a 2020. január 1-tôl 2021. március 1-ig megjelent közleményekben. A kulcsszavak az alábbiak voltak: COVID-19, kórházon kívüli szívmegállás, kórházon belüli szívmegállás, kimenetel. Ezenkívül bevontuk az így talált közlemények releváns referenciáit. Összesen 223 tanulmányt azonosítottunk. Ebből kizártuk a kétszeresen előforduló dolgozatokat, az esettanulmányokat, a kommentárokat, illetve azon közleményeket, melyek a vizsgálandó témával nem voltak szakmailag összevethetők (összesen 188). 
A megmaradt 35 tanulmány teljes átolvasása után további 17 munka került kizárásra kis esetszám, átfedő populációs mintavétel, illetve a csak a kórházba szállított, sikeresen újraélesztett esetek bevonása miatt, így végezetül összesen 18 közlemény összefoglalását végeztük el. A beválasztott tanulmányok között szerepeltek szisztematikus áttekintő tanulmányok (2), egycentrumos retrospektív megfigyeléses vizsgálatok (12), multicentrikus retrospektív megfigyeléses vizsgálatok (2), valamint egy egycentrumos és egy országos prospektív obszervációs vizsgálat.

\section{Kórházon kívüli szívmegállás - incidencia és mortalitás a pandémia előtt és alatt}

A járvány káros hatása a népesség egészségi állapotára nézve a kórházon kívüli szívmegállás előfordulásával jól szemléltethető. Az elmúlt egy évben általánosságban a különböző tanulmányok a kórházon kívüli szívmegállás incidenciájának emelkedését tapasztalták világszerte (1. táblázat) [4, 5, 8, 10, 17-26].

Lim és mtsai a szisztematikus áttekintő tanulmányukban 10 közlemény elemzését végezték el, ennek során a SARS-CoV-2 okozta járvány alatti, kórházon kívüli szívmegállás előfordulását elemezték [5]. Az általuk vizsgált 10 kutatásból 6 végzett közvetlen összehasonlítást a kórházon kívüli szívmegállás incidencáját illetően 2019 és 2020 azonos időtartama között. 2019-ben 4018, kórházon kívüli szívmegállást rögzítettek, míg 2020 azonos időszakában 8822-t, ami összességében 119,6\%-os növekedést jelent $(\mathrm{p}<0,001)[4,5,8,17-20]$.

A járvány alatt a 10 kutatás összesen 11 590, kórházon kívüli szívmegállásról számolt be, melyek közül 10992 $(98,8 \%)$ esetnél volt elérhető adat a végkimenetról, ebből $9328(84,9 \%)$ beteg hunyt el. Ezzel ellentétben a pandémiát megelőző különböző időszakokban összesen 22 319, kórházon kívüli szívmegállásról számoltak be, ezekből 13831 (62\%) végződött halállal $(\mathrm{p}<0,001)$ [5].

A kórházon kívüli szívmegállás incidencája és az általa okozott mortalitás nem volt egyenlő mértékü a világ különböző pontjain. Míg Lombardiában (Észak-Olaszország) [7, 17], Párizsban (Franciaország) [4], New Yorkban (USA) [8] és Londonban (Egyesült Királyság) [21] jelentős növekedésről számoltak be, addig Észak-Olaszország tartományaiban [18] és az USA [22] más szövetségi államaiban nem tapasztalták ugyanezt az emelkedést.

A hirtelen szívmegállást szenvedettek közül igazoltan SARS-CoV-2-pozitív betegek Olaszországban 3,9\%ban, Dél-Koreában 4,3\%-ban, Franciaországban 4,8\%ban, az USA-ban pedig 5,9\%-ban fordultak elő. COVID-19-hez köthető tüneteket - úgymint köhögés, láz, dyspnoe - a következő százalékos arányban jelentettek: $26 \%, 18 \%, 8,1 \%$ és $4,8 \%[4,8,10,17,23]$. London- ban a kórházon kívüli szívmegállást szenvedettek 24,5\%-a volt vagy igazoltan SARS-CoV-2-fertőzött, vagy rendelkezett valamilyen, a betegségre jellemző tünettel [21].

\section{A kórházon kívüli szívmegállás okai, helyszíne és a betegek demográfiai sajátosságai}

A Lim és mtsai által végzett szisztematikus tanulmányban megegyező arányban szerepelt belgyógyászati ok a kórházon kívüli szívmegállás hátterében a járványt megelőzően, illetve a járvány alatt (90\% [12 693/14 105] vs. 90,5\% [1669/1845]. Ezzel szemben traumához köthető szívmegállás gyakoribb volt a járvány előtti években (8,9\% (1253/14 105) vs. 7,4\% (136/1845) [5].

A kórházon kívüli szívmegállás helyszíne jellemzően a betegek otthona volt. Hat vizsgálat eredményei alapján $4837 / 6645$ (72,8\%), kórházon kívüli szívmegállás történt otthon a járványt megelőzően, míg 1997/2376 (84\%) a járvány ideje alatt $(\mathrm{p}<0,0001)$ (2. táblázat) $[4,5,7,8,17-26]$.

A hirtelen szívhalált szenvedett betegek demográfiai adatai hasonlóak voltak a SARS-CoV-2-pandémia alatt és előtt, New York [8] és London [21] kivételével, ahol a járvány alatti betegek idősebbek voltak, kisebb százalékban tartoztak a kaukázusi rasszba, és nagyobb valószínûséggel szenvedtek valamilyen társbetegségben (hypertonia, diabetes) [10].

\section{Szemtanú jelenléte és az alapszintü újraélesztés}

A járvány alatt alacsonyabb arányban fordult elő szemtanú előtti szívmegállás Olaszországban, Franciaországban és az USA-ban, valamint hasonlóan alacsonyabb számban történt szemtanú által megkezdett BLS Olaszországban $(35 \%$ vs. $45 \%, \mathrm{p}=0,02)$ és Franciaországban (48\% vs. 64\%, p<0,001), amint az a Scquizzato és mtsai által készített szisztematikus összefoglaló tanulmányból kiderül [10]. Ezzel ellentétben az USA-ban [8] és DélKoreában [23] nem okozott változást a járvány megléte a BLS megkezdésében, míg Londonban épp az ellenkezőjét figyelték meg: a járvány alatt jelentősen több betegnél kezdtek meg BLS-t $(63,3 \%$ vs. $52,6 \%, \mathrm{p}<0,001)$ [21].

Olaszországban a COVID-19-tünetekkel rendelkező betegek kisebb valószínúséggel részesültek BLS-ben azokkal a betegekkel ellentétben, akiknél a fertőzés lehetősége nem merült fel (2. táblázat) [4, 5, 7, 8, 17-26].

Arra vonatkozó adat nem állt rendelkezésre, hogy a mellkaskompressziós és befúvásos lélegeztetést, illetve a csak mellkaskompressziós újraélesztést milyen arányban alkalmazták $[10,17]$. 


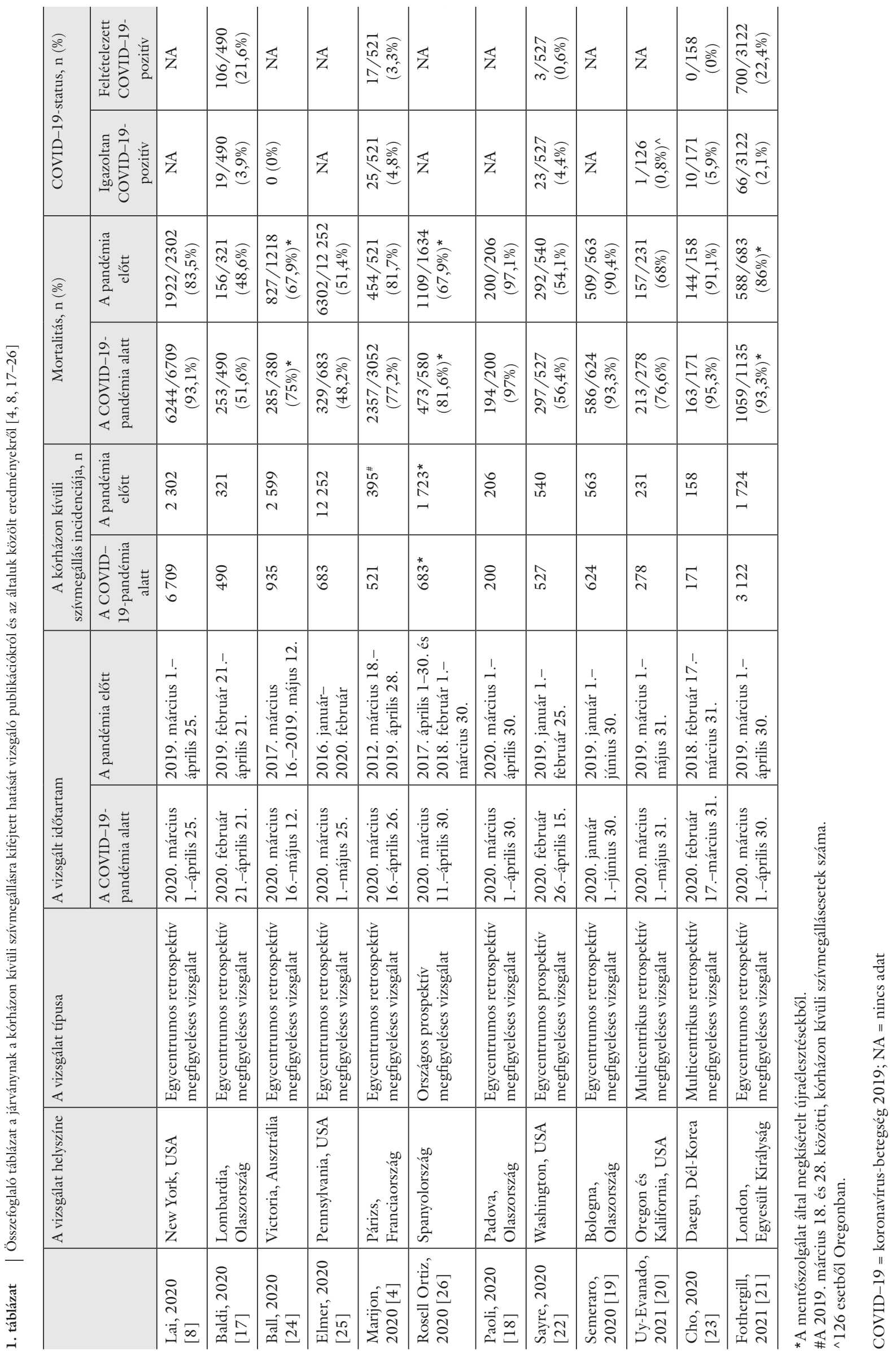




\begin{tabular}{|c|c|c|c|c|c|c|c|c|c|c|c|c|c|c|}
\hline 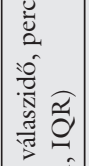 & 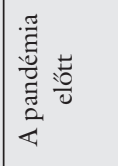 & 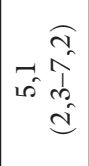 & $\approx \frac{\widehat{L}}{a}$ & 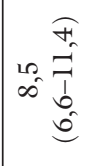 & $\overleftrightarrow{z}$ & 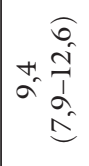 & $\approx \frac{\widehat{a}}{\infty}$ & 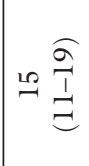 & $\overleftrightarrow{z}$ & $a \frac{\pi}{n}$ & 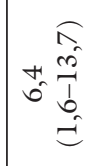 & $\begin{array}{l}\infty \\
0 \\
0\end{array}$ & 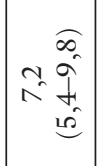 & \\
\hline 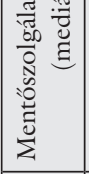 & 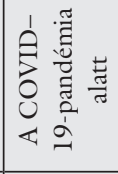 & $\begin{array}{c}\hat{b} \\
0 \\
\text { in } \\
\text { in } \\
\text { a }\end{array}$ & 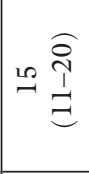 & 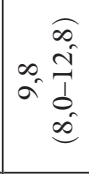 & 㐏 & 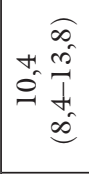 & 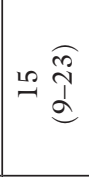 & 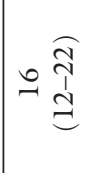 & $\overleftrightarrow{Z}$ & $a \frac{\widehat{I}}{\triangleq}$ & $\begin{array}{l}0 \\
\infty \\
\wedge \\
\hat{N} \\
\hat{1} \\
\hat{e}\end{array}$ & $\infty$ & 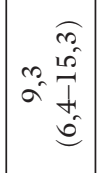 & \\
\hline$\frac{\partial}{a}$ & 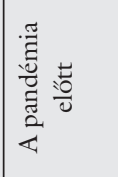 & 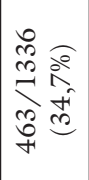 & 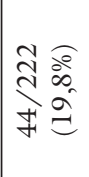 & 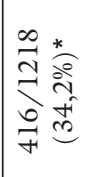 & 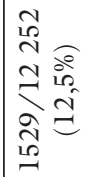 & $\overleftrightarrow{Z}$ & 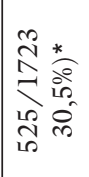 & 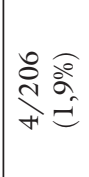 & $\overleftrightarrow{z}$ & 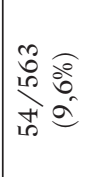 & 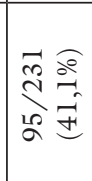 & 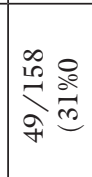 & 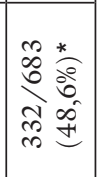 & \\
\hline 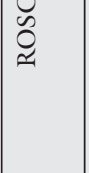 & 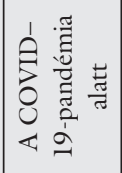 & 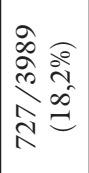 & 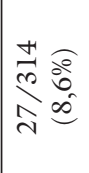 & 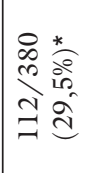 & 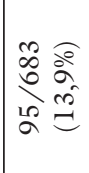 & $\overleftrightarrow{Z}$ & 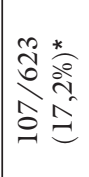 & 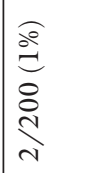 & $\overleftrightarrow{Z}$ & 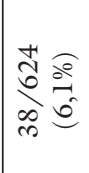 & 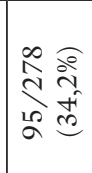 & 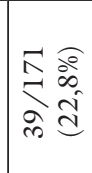 & 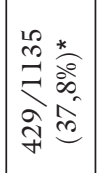 & \\
\hline 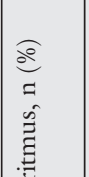 & 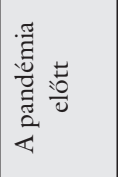 & 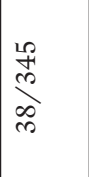 & 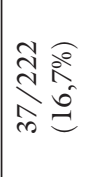 & 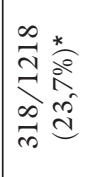 & $\overleftrightarrow{Z}$ & 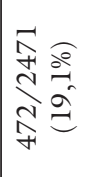 & 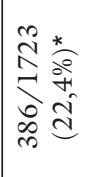 & $\overleftrightarrow{z}$ & $\overleftrightarrow{Z}$ & 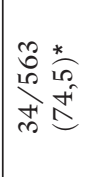 & 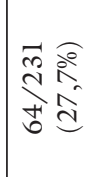 & 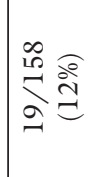 & 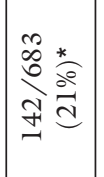 & \\
\hline 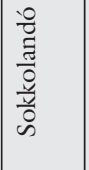 & 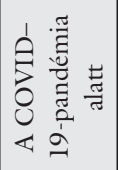 & 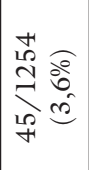 & 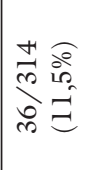 & 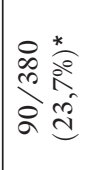 & $\overleftrightarrow{z}$ & 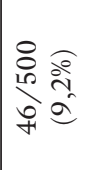 & 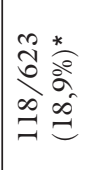 & $\overleftrightarrow{z}$ & $\overleftrightarrow{Z}$ & 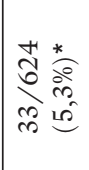 & 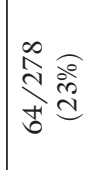 & 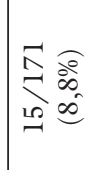 & 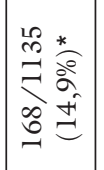 & 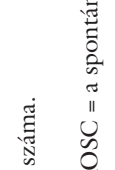 \\
\hline 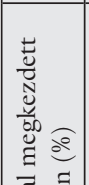 & 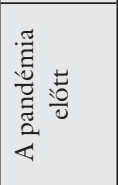 & 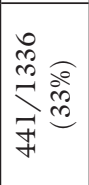 & 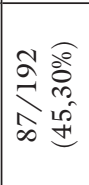 & 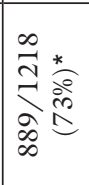 & 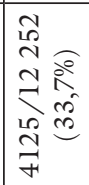 & 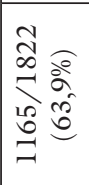 & 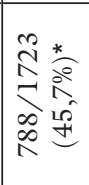 & 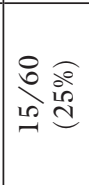 & 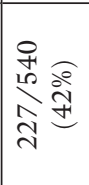 & 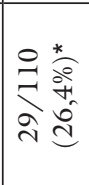 & 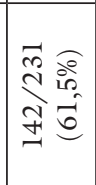 & 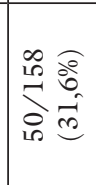 & 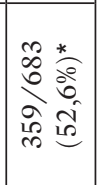 & 竞 \\
\hline 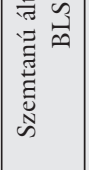 & 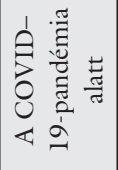 & 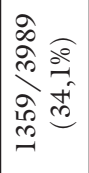 & 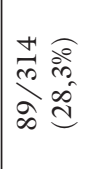 & 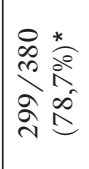 & 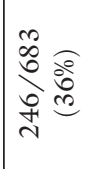 & 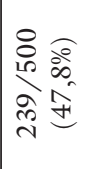 & 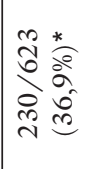 & 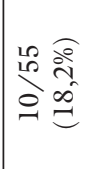 & 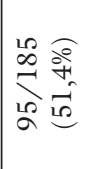 & 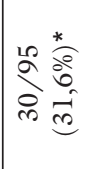 & 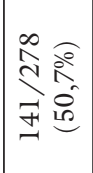 & 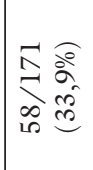 & 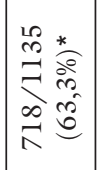 & 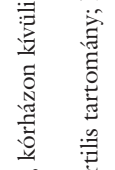 \\
\hline 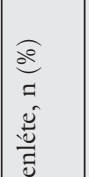 & 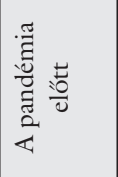 & 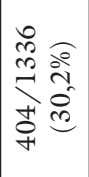 & 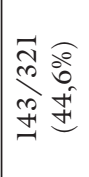 & 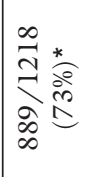 & 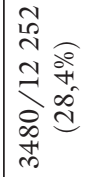 & 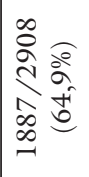 & 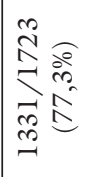 & 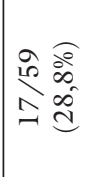 & $\vec{z}$ & $\overleftrightarrow{z}$ & 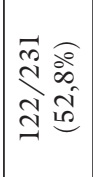 & 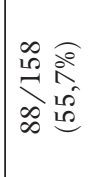 & 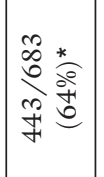 & â" \\
\hline 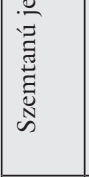 & 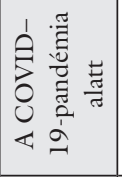 & 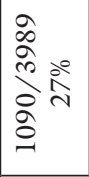 & 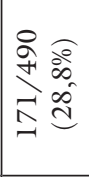 & 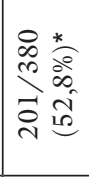 & 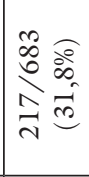 & $\mid \begin{array}{cc}8 & 0 \\
0 & 0 \\
0 & 0 \\
0 & 0 \\
\text { in } & 0\end{array}$ & 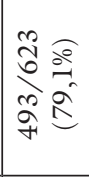 & 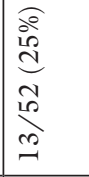 & $\vec{z}$ & $\overleftrightarrow{\mathrm{z}}$ & 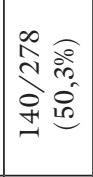 & 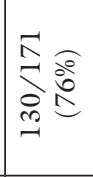 & 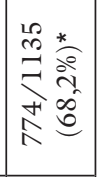 & 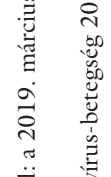 \\
\hline 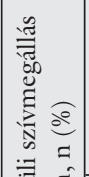 & 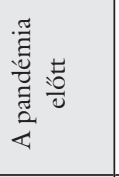 & $\overleftrightarrow{z}$ & 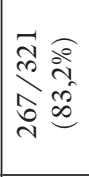 & 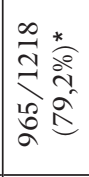 & $\overleftrightarrow{\mathrm{z}}$ & 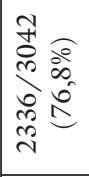 & 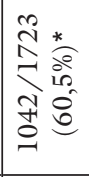 & $\overleftrightarrow{\mathrm{Z}}$ & $\overleftrightarrow{Z}$ & 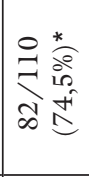 & 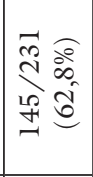 & 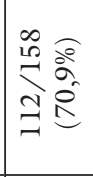 & 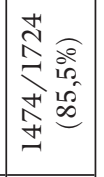 & 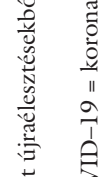 \\
\hline 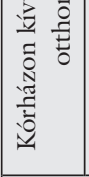 & 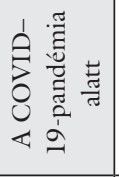 & $\mathbb{z}$ & 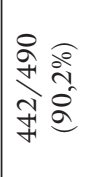 & 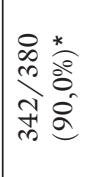 & $\overleftrightarrow{z}$ & 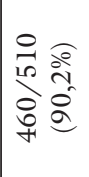 & 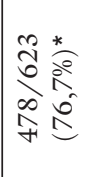 & $\overleftrightarrow{Z}$ & $\overleftrightarrow{z}$ & 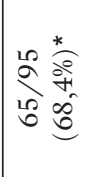 & 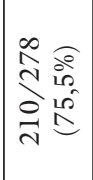 & 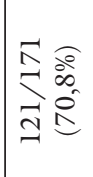 & 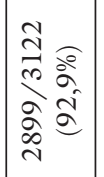 & 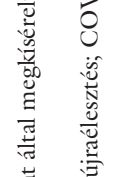 \\
\hline & & 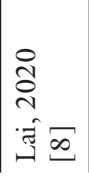 & 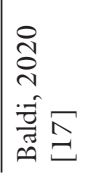 & 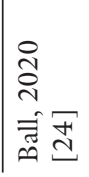 & 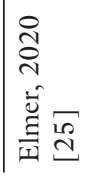 & 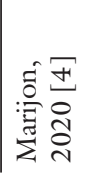 & 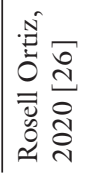 & 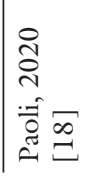 & 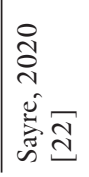 & 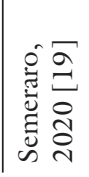 & 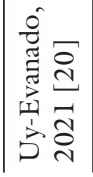 & 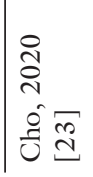 & 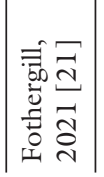 & $\frac{3}{4}$ \\
\hline
\end{tabular}




\section{Iniciális ritmus és félautomata defibrillátor alkalmazása}

A nem sokkolandó ritmus (pulzus nélküli elektromos aktivitás [PEA] és asystolia) előfordulása több mint 10\%kal emelkedett New Yorkban [8], Párizsban [4] és Londonban [21] a járvány alatt. Hasonló emelkedést tapasztaltak Olaszországban [17] és Dél-Koreában [23] is, még ha ez nem is bizonyult szignifikáns különbségnek a járványt megelőző évhez képest (2. táblázat) $[4,5,7$, $8,10,17-26]$.

A Lim és mtsai áttekintő tanulmányában 5 kutatást hasonlított össze a félautomata defibrillátor használatát illetően a járvány alatt és előtt. A pandémiát megelőző időszakban gyakoribb volt a defibrillátor használata a pandémia alatti időszakhoz képest $(12,4 \%$ vs. $6,8 \%$, $\mathrm{p}<0,001)[4,5,20,24-26]$.

\section{Mentöszolgálat}

A Scquizzato és mtsai által írt szisztematikus összehasonlító tanulmányba bevont valamennyi publikáció a különböző országok mentőszolgálatainak megnövekedett reakcióidejéról számol be [10]. A járvány alatt jelentős késést tapasztaltak Olaszországban $(+1-3$ perc) $[7,17]$ és Dél-Koreában (+1 perc) [23] is az előző évhez képest. Londonban a 999-segélyhívás és a mentők helyszínre érkezése közötti intervallum, a helyszínen töltött teljes időtartam, valamint a 999-hívás és a kórházba érkezés között eltelt idő mind hosszabb volt a járvány alatt a megelőzó évhez képest $(9,3$ vs. 7,2 perc, $\mathrm{p}<0,001 ; 61,8$ vs. 52,3 perc, $\mathrm{p}<0,001 ; 86,4$ vs. 74,4 perc, $\mathrm{p}<0,001)$ (2. táblázat) $[4,5,7,8,17-26]$.

A mentőszolgálat által megkezdett prehospitális resuscitatio aránya jelentős mértékben csökkent egy Olaszországban (39\% vs. 53\%, p = 0,048) és Franciaországban (53\% vs. 66\%, p<0,001) végzett vizsgálatok alapján [10]. Londonban is kevesebb újraélesztési kísérlet történt a járvány alatt, ez a különbség szignifikánsnak bizonyult $(36,4 \%$ vs. $39,6 \%, \mathrm{p}=0,03)[21]$.

Lai és társai alacsonyabb számú mentőszemélyzet által megkísérelt endotrachealis intubációról $(-28,0 \%)$ és maszkos lélegeztetésról $(-7,4 \%)$ számoltak be New Yorkban a járvány ideje alatt, a supraglotticus légútbiztosító eszközök használata azonban 20\%-os növekedést mutatott $[8,21]$.

\section{A spontán keringés visszatérése (ROSC), túlélés a kórházi elbocsátásig}

Olaszországban és New Yorkban végzett vizsgálatok alapján szignifikánsan alacsonyabb számban értek el spontán keringés-visszatérést a hirtelen szívhalált szenvedett betegek esetében a járvány alatt az azt megelőző évhez képest. Észak-Olaszországban a spontán keringés visszatérésének előfordulása 19,8\%-ról 8,6\%-ra (p<0,001)
[17], míg New Yorkban 35\%-ról 18\%-ra (p<0,001) csökkent [8]. Egy multivariáns analízis kimutatta, hogy a járvány alatt a New Yorkban kórházon kívüli szívmegállást szenvedett betegek esetében $41 \%$-kal kisebb eséllyel tért vissza a spontán keringés (2. táblázat) $[4,5,7,8,10$, 17-26].

A kórházi elbocsátásig való túlélést három vizsgálat [4, 17, 23] elemezte a Scquizzato és mtsai [10] által bevont kutatásokból, ezenkívül egy említést tesz a kórházon kívüli szívmegállást követő jó neurológiai kimenetel előfordulásáról [26]. Franciaországban a kórházon kívüli szívmegállást szenvedett betegek kisebb százalékban élték meg a kórházi elbocsátást a járvány alatt $(3,1 \%$ vs. $5,4 \%, \mathrm{p}<0,001)$ [4]. Statisztikailag nem szignifikáns csökkenést figyeltek meg Olaszországban [17] és DélKoreában [23] is. Azon betegek aránya, akiket jó neurológiai funkcióval sikeresen elbocsátottak a kórházból 5,7\%-ról 2,9\%-ra csökkent $(\mathrm{p}=0,09)$ Dél-Koreában a pandémia alatt $[10,23]$.

\section{Kórházon belüli szívmegállás}

A COVID-19-et megelőzően évente mintegy 290000 felnőtt szenvedett kórházon belüli szívhalált az USA-ban [27, 28]. A kórházon belüli szívmegállás gyakran váratlanul jelentkezik, és bármelyik kórházban ápolt beteget érinthet. Noha a legtöbb, kórházon belüli szívmegállás az általános kórházi osztályokon történik [29, 30], jelentős számban jelentkezhet az intenzív osztályokon is [31]. A kórházon belüli szívmegállás incidenciája nagy változatosságot mutat az irodalomban található különböző források szerint (1-5/1000 kórházi felvétel) [27, 28]. A túlélés a kórházi elbocsátásig 13\% és 22\% körül mozgott világszerte a járványt megelőző időszakban [32].

Az első megjelent publikáció a kórházon belüli szívmegállásról a COVID-19-betegek körében - melyet Vuhanban, a súlyos COVID-19-pneumoniában szenvedők ellátására kijelölt központi egyetemi klinikán végeztek 13,2\%-os ROSC-rátáról és kevesebb mint 2,9\%-os 30 napos túlélésról számolt be. Mivel asystolia volt a leggyakoribb iniciális ritmus, a szerzők aggodalmukat fejezték ki az elérhető orvosi eróforrásokkal és a resuscitatio minőségével kapcsolatban [33]. Hasonlóan, egy retrospektív, egycentrumos tanulmány, mely 31 COVID-19-beteg kórházon belüli szívmegállást követő túlélését vizsgálta egy New York-i intézményben, azt találta, hogy az általuk vizsgált adatok szerint a 31 betegból 1 sem élte meg a kórházi elbocsátást $[34,35]$. Egyelőre még nem tisztázott, hogy a megjelent magas halálozási adatok hátterében mi rejlik: befolyásoló tényező lehet a betegség lefolyása, illetve a súlyos klinikai állapot foka, vagy a szívmegállást szenvedett COVID-19-betegek szervezeti megközelítése és az újraélesztés minősége (3. táblázat) [33-36].

Yuriditsky és mtsai 110, kórházon belüli újraélesztésen átesett beteg adatait dolgozták fel [35]. A tanulmányba bevont betegek fele COVID-19-ben szenvedett, akik- 


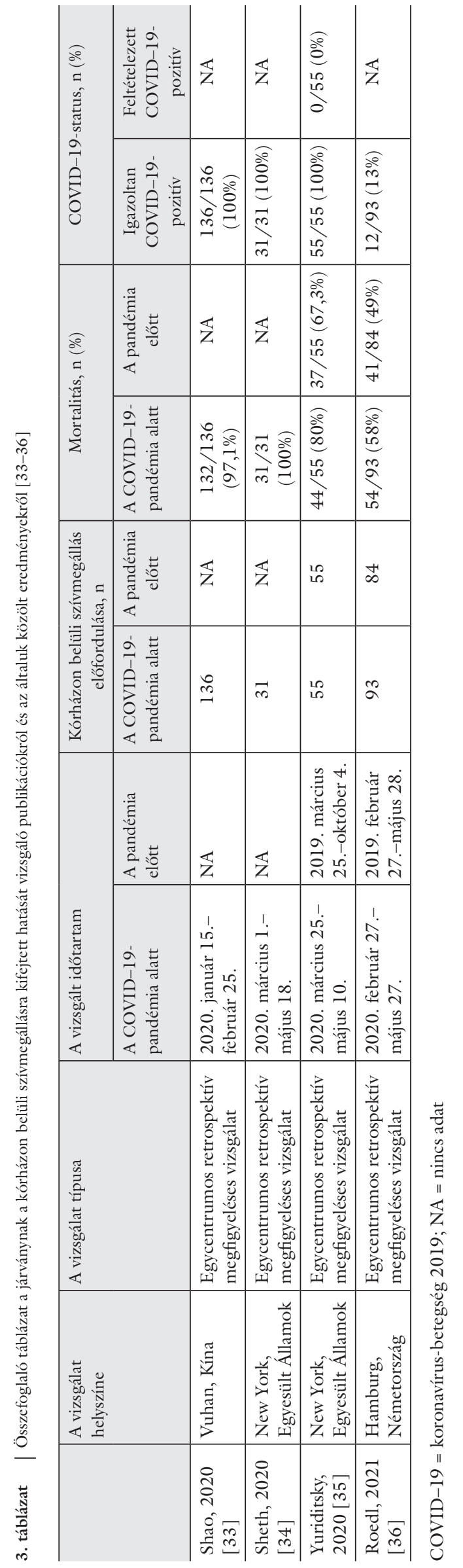

\begin{tabular}{|c|c|c|c|c|c|c|c|c|c|}
\hline \multirow{2}{*}{ 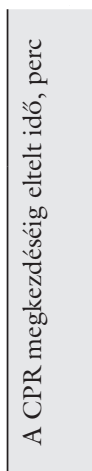 } & 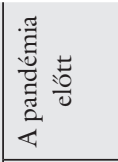 & $\overleftrightarrow{z}$ & & \multicolumn{2}{|l|}{$\overleftrightarrow{\mathrm{z}}$} & \multicolumn{2}{|l|}{ 㐏 } & 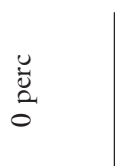 & 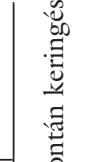 \\
\hline & 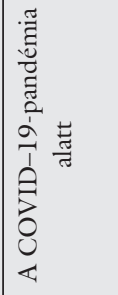 & 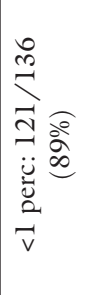 & 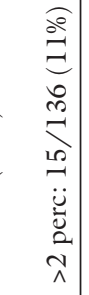 & $\overleftrightarrow{z}$ & & $\overleftrightarrow{z}$ & & 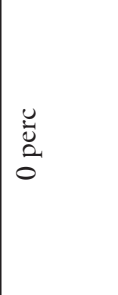 & 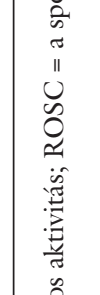 \\
\hline \multirow{2}{*}{$\begin{array}{l}\text { o } \\
\vdots \\
0 \\
0 \\
0 \\
\approx\end{array}$} & 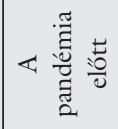 & 壳 & & $\overleftrightarrow{z}$ & & 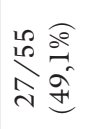 & & 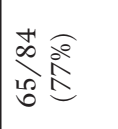 & $\frac{\vec{D}}{\frac{\vec{U}}{\underline{u}}}$ \\
\hline & 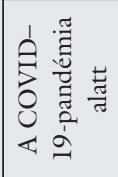 & 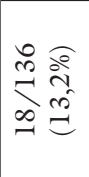 & & 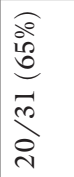 & & 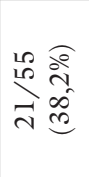 & & 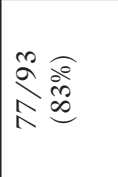 & 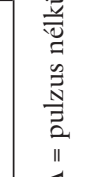 \\
\hline \multirow{4}{*}{ 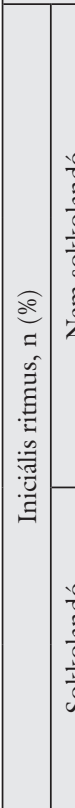 } & 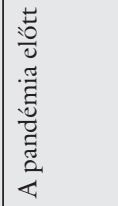 & $\overleftrightarrow{z}$ & & 艺 & & 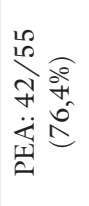 & 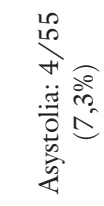 & 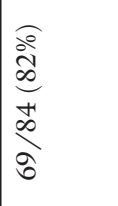 & 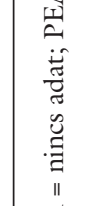 \\
\hline & 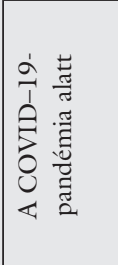 & 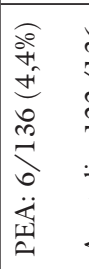 & 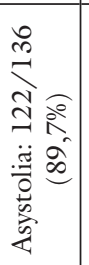 & 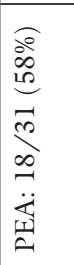 & 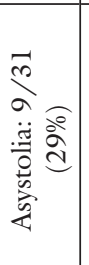 & 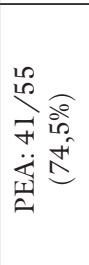 & 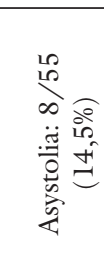 & 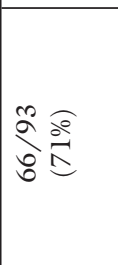 & 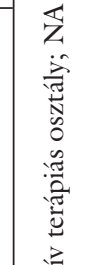 \\
\hline & 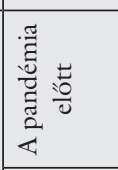 & $\overleftrightarrow{z}$ & & 艺 & & 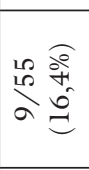 & & $\begin{array}{l}1 \\
\infty \\
10 \\
10\end{array}$ & $\begin{array}{l}. \pm \\
.11 \\
0 \\
G\end{array}$ \\
\hline & 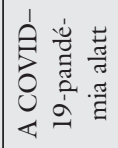 & 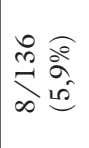 & & 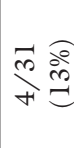 & & 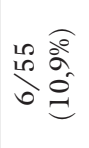 & & 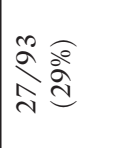 & 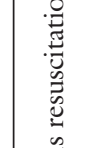 \\
\hline \multirow{2}{*}{ 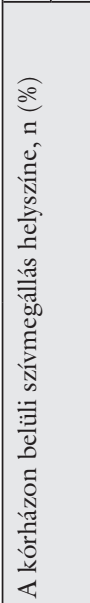 } & 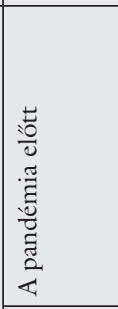 & $\overleftrightarrow{z}$ & & $\overleftrightarrow{z}$ & & 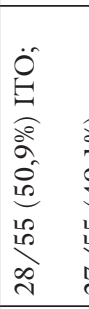 & 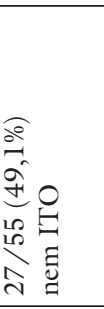 & 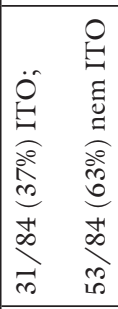 & 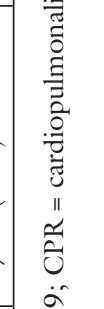 \\
\hline & 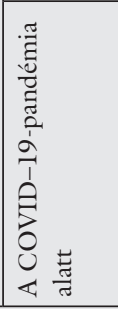 & 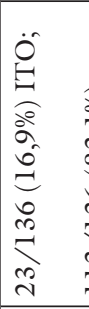 & 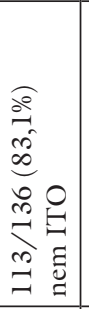 & 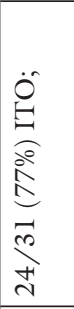 & 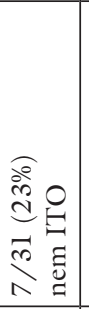 & 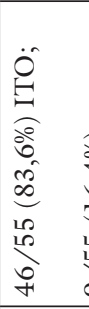 & 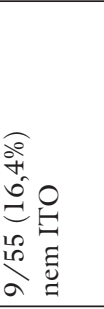 & 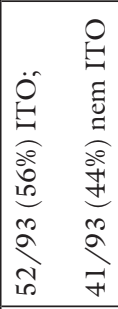 & 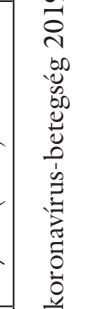 \\
\hline & & 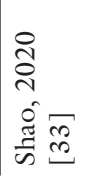 & & 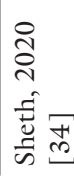 & & 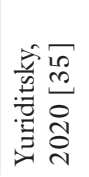 & & 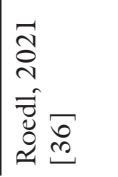 & 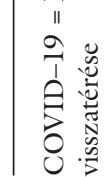 \\
\hline
\end{tabular}


nek a jellemzőit összehasonlították a COVID-19-ben nem szenvedő betegek jellemzóivel. A COVID-19-betegek hirtelen szívhalálának hátterében nagyobb eséllyel állt respiratorikus ok, és az iniciális ritmus magasabb arányban volt PEA, a COVID-19-ben nem szenvedő csoporttal ellentétben. Míg a cardiopulmonalis resuscitatio (CPR) medián időtartama szignifikánsan rövidebb volt a COVID-19-csoportban (10 perc vs. 22 perc), addig a spontán keringés visszatértében (38,2\% vs. 49,1\%, $\mathrm{p}=0,336)$ és a 30 napos túlélésben nem észleltek különbséget a két csoport között $(20 \%$ vs. $32,6 \%, \mathrm{p}=$ $0,194)$. Ez éles kontraszt a Vuhanban jelentett magas mortalitási adatokkal szemben (4. táblázat) [33-36].

Roedl és mtsai a járvány hatását vizsgálták a kórházon belüli szívmegállásra nézve [36]. A vizsgálati időintervallum alatt - 2020-ban - a kórházi felvételek száma 18 262-ről 13 994-re mérséklődött az előző évhez képest, ami 23\%-os csökkenést jelent. A kórházon belüli szívmegállás incidenciája azonban 4,6-ról 6,6/1000 kórházi felvételre nőtt. A kórházon belüli szívmegállás helyszíne az intenzív osztályra tolódott a járvány ideje alatt $(56 \%$ vs. $37 \%, \mathrm{p}<0,01)$. A mortalitásban nem volt jelentős különbség a két időintervallum között (49\% [2019] vs. 58\% [2020], p = 0,14). A kórházon belüli szívmegállást szenvedettek közül összesen 43 beteg jelentkezett a súlyos légzési elégtelenség tüneteivel, ebből 12 beteg igazoltan SARS-CoV-2-fertőzött volt. A két alcsoport adatait összehasonlítva azt találták a szerzők, hogy a Horowitz-kvóciens $\left(\mathrm{PaO}_{2} / \mathrm{FiO}_{2}\right.$ arány) szignifikánsan alacsonyabb volt a COVID-19-betegek körében $(\mathrm{p}<0,01)$, igazolva azt, hogy a COVID-19 súlyos tüdőkárosodással jár. Emellett érdekes módon a resuscitatiós idő is alacsonyabbnak bizonyult a COVID-19-betegek esetében $(\mathrm{p}<0,01)$. A COVID-19-csoportban jóval nagyobb arányban észleltek kedvezóbb neurológiai kimenetelt, mint a COVID-19-ben nem szenvedők esetében (COVID-19: 42\% vs. nem COVID-19: 10\%) [36].

\section{Megbeszélés}

A SARS-CoV-2-járvány alatt jelentős emelkedést figyelhetô meg mind a kórházon kívüli, mind a kórházon belüli szívmegállás előfordulásában $[5,10,36]$. Az általános trend azt mutatja, hogy a kórházon kívüli szívmegállás a járvány ideje alatt nagyobb gyakorisággal járt nem sokkolandó ritmussal, hosszabb idő telt el a mentők kiérkezéséig, valamint alacsonyabb volt a spontán keringés visszatértének és a kórházi elbocsátásnak a gyakorisága. A COVID-19-nek a kórházon belüli szívmegállásra kifejtett hatása kevésbé vizsgált az irodalomban, a mortalitási mutatók éles ellentétet mutatnak a különböző tanulmányokban.

A kórházon kívüli szívmegállás nagyobb incidenciájában a járványnak mind közvetlen, mind közvetett úton szerepe lehet. A SARS-CoV-2-fertózésre adott túlfokozott immunválasz, mely citokinviharhoz és többszervi elégtelenséghez vezethet, valamint az akut respirációs distressz szindróma (ARDS) kialakulása a betegek halálát okozhatja [37]. Ebből kifolyólag elképzelhető, hogy a pandémia alatt látott, kórházon kívüli szívmegállásesetek egy része valójában az otthon maradt COVID-19-betegek légzési elégtelenségének következménye. Több vizsgálat is beszámolt a nem sokkolandó ritmus többségéról a járvány alatt $[5,10,21]$. A hypoxia az egyik leggyakoribb oka a nem sokkolandó ritmusoknak, és gyakran jár együtt rossz kimenetellel [10]. Akut cardiovascularis eseményeket, mint például akut coronaria szindrómát, tüdőemboliát, illetve szívelégtelenséget és különböző arrhythmiákat is megfigyeltek a COVID-19-betegek körében, ezek alapján elképzelhető, hogy a kórházon kívüli szívmegállás a COVID-19 egyik direkt komplikációja lehet [4]. Végezetül a SARS-CoV-2-infekció nagyfokú prothromboticus állapottal járhat együtt, mely tüdőembolia, illetve akut myocardialis infarctus kialakulásához vezethet [4].

Fontos kiemelni azonban, hogy a kórházon kívüli szívmegállás incidencája és az általa okozott mortalitás nem volt egyenlő mértékű a világ különböző pontjain. Míg Lombardiában [7, 17], Párizsban [4], New Yorkban [8] és Londonban [21] jelentős növekedésról számoltak be, addig Észak-Olaszország tartományaiban [18] és az USA [22] más szövetségi államaiban nem tapasztalták ugyanezt az emelkedést. Ennek a területi eltérésnek a pontos okai a mai napig tisztázatlanok, ám felmerül a kérdés, hogy a COVID-19 közvetlen haláloka mellett a járvány közvetett úton is szerepet játszik-e az elmúlt egy évben megfigyelt többlethalálozásban [10]. Lombardiában a járvány alatt megfigyelt, kórházon kívüli többletszívmegállás 74\%-át közvetlenül a COVID-19-nek tulajdonították, míg Franciaországban ez az arány alacsonyabb volt, összesen 33\% [4, 10, 17]. A fennmaradó esetekért feltételezhetően szintén a járvány indirekt hatása lehet felelős. A kijárási korlátozások bevezetésével és az egészségügy átrendezésével a betegek nehezebben fértek hozzá a szükséges orvosi ellátáshoz. Ezenkívül a megfertőzéstől való félelem és a hosszú várólisták is hozzájárulhattak ahhoz, hogy a betegek alacsonyabb arányban látogatták a kórházakat és az orvosi rendelóket [4]. Figyelembe véve, hogy a kórházon kívüli szívmegállás hátterében a leggyakrabban myocardialis ischaemia áll, a 2020-ban megfigyelt, csökkent számú kardiológiai és ST-elevációs myocardialis infarctus miatti kórházi felvétel [38] hozzájárulhatott az emelkedett számú hirtelen szívhalálhoz, hiszen ez azt valószínúsíti, hogy a betegek ezen kórképekkel nem jutottak megfelelő ellátáshoz [39]. Végezetül a félelem, a bezártság és adott esetben a pácienseknek a szeretteik elvesztése miatti gyásza következtében kialakult pszichológiai stressz is képes különböző szívbetegségeket triggerelni, amelyek akár hirtelen szívmegálláshoz vezethetnek [4].

Amellett, hogy a kórházon kívüli szívmegállás incidenciája emelkedett, a hirtelen szívmegállás utáni túlélés is drasztikusan csökkent. A túlélési lánc megbomlása világ- 
szerte megfigyelhető volt, ami részben hozzájárulhatott a kedvezőtlen kimenetelhez.

Annak ellenére, hogy a legtöbb hirtelen szívmegállás otthon történt, gyakrabban fordult elő kórházon kívüli szívmegállás szemtanú hiányában. Ennek hátterében többek között a szigorú karantén állhat, amely miatt a veszélyeztetett populáció - mint például az idősek - izolációja következett be az egyébként gyakran látogató családtagoktól. A „Maradj otthon!” kampány következtében nem meglepő, hogy szignifikánsan több hirtelen szívmegállás történt otthon - ezt jelzi a csökkent számú traumához köthető szívmegállás is -, ahol akár karantén következtében az adott vulnerábilis személy a család többi tagjától elkülönülhetett, illetve ez magyarázhatja a defibrillátorkészülékek csökkent használatát, hiszen a betegek otthonában a készülék nem volt elérhető, ami pedig a defibrilláció késlekedéséhez vezethetett [5].

A közösségi szerepvállalás a túlélési lánc elindításában és fenntartásában nélkülözhetetlen, ez azonban a járvány következtében jelentősen meggyengült. Olaszországban és Franciaországban a BLS megkezdésének csökkent elöfordulásáról számoltak be $[4,17]$. Sokszor a megfertőződéstől való félelem szabott gátat a BLS kivitelezésének [10]. Lim és mtsai feltételezése szerint, ha a szemtanú a beteg valamelyik családtagja volt - hiszen a legtöbb esetben a kórházon kívüli szívmegállás otthon történt -, a pszichológiai és emocionális sokk miatt talán nem voltak képesek arra, hogy megkezdjék az újraélesztést [5]. Ám éppen ennek az ellenkezőjéről számoltak be Fothergill és mtsai, akik Londonban a szemtanú által megkezdett BLS emelkedett előfordulásáról írtak. Ők éppen azzal magyarázták ezt az emelkedést, hogy egy családtagnak a megfertőződéstől való félelem ellenére nagyobb lehetett a motivációja arra, hogy segítséget nyújtson [21].

A járvány alatt az egyes országok mentőszolgálatainak megnövekedett válaszidejéről több tanulmány is beszámolt, ami szintén magyarázhatja a nem sokkolandó ritmusok gyakoribb előfordulását és az alacsony túlélési rátát [10]. A mentôszolgálat túlterhelése, valamint a különböző új protokollok bevezetése mind szerepet játszhatnak ebben. Észak-Olaszországban a késés a leggyakrabban a hívás fogadásában és a mentőszolgálat indulásában volt. Ezek a késések könnyen magyarázhatók a diszpécserek emelkedett munkaterhelésével, valamint azzal a ténnyel, hogy a segélyhívás rögzítésekor külön kérdéseket kellett feltenni a COVID-19-statusról és a fertőzésre jellemző tünetekről [10]. Londonban ezzel ellentétben mindenkit fertőzöttnek tekintettek [21]. A mentőszolgálatok ellátói kötelezően védőfelszerelésben végezték a betegellátást a pandémia alatt, amelynek a felvétele elkerülhetetlenül akár percekkel növelhette a helyszínre való kiérkezést. A védőfelszerelés megfelelő használata elengedhetetlen a szakemberek védelme szempontjából, azonban nehézséget tud okozni az újraélesztés kivitelezésében mind fizikailag, mind pedig a nem technikai készségeket illetően, úgymint a csapattagok közötti kommunikáció, ami pedig összességében az újraélesztés minőségének romlásához vezethet $[40,41]$. A járvány alatt két, Európában kivitelezett tanulmány írt arról, hogy a mentőszolgálat kevesebb alkalommal kezdte meg a betegek resuscitatióját $[4,7]$. Ennek hátterében az a nem éppen optimista hozzáállás lehet, hogy többségében azoknak a betegnek az újraélesztését kezdték meg, akiknek nagyobb esélyük volt a túlélésre (szemtanú jelenléte, BLS megkezdése, sokkolandó ritmus). Mindemellett a kórházak és intenzív osztályok részleges vagy teljes/túl telítettségének tudata és ismerete is szerepet játszhatott ebben [10].

Annak kockázata, hogy az újraélesztést végző személy megfertőződjön, több tényezőtől is függ. Elsősorban függ a COVID-19 prevalenciájától a hirtelen szívmegállást szenvedők körében, valamint a transzmisszió valószínûségétől, ami a különböző SARS-CoV-2-variánsok között eltérő lehet. Az irodalomban leírt COVID19-prevalencia a kórházon kívüli szívmegállást szenvedett betegpopulációban nem volt elenyésző. Az igazoltan SARS-CoV-2-pozitív betegek aránya 3,9\% és 5,9\% között mozgott az idézett publikációkban, míg a COVID-19-re jellemző tünetekkel (láz és köhögés vagy dyspnoe) rendelkező betegek aránya 4,8\% és 26\% között [10]. Mint azt az International Liaison Committee on Resuscitation (ILCOR) hangsúlyozta: a kórházon kívüli szívmegállás szemtanúi valószínúleg már eleve ki voltak téve a megfertőződés veszélyének, ha az otthon szívmegállást szenvedett személy SARS-CoV-2-pozitív volt $[10,42]$. Azt azonban fontos megjegyezni, hogy az újraélesztés növelheti a fertőző kórokozót tartalmazó aeroszol képződésének rizikóját, ami a szemtanúk, valamint a prehospitális személyzet biztonsága szempontjából ugyanannyira fontos. Azért, hogy az ellátók megfertőződésének rizikója csökkenjen, az Európai Újraélesztési Tanács (European Resuscitation Council, ERC) többek közt azt javasolta, hogy az alapszintű ellátók kerüljék a szájból szájba lélegeztetést, és csak mellkaskompressziót végezzenek [43]. Ebből kifolyólag a pandémia alatt még nagyobb relevanciája lett azon közösségi kampányoknak, melyek a lélegeztetés nélküli mellkaskompressziót népszerüsítik, valamint azon törekvéseknek, melyek Nyugat-Európában már egyre inkább elterjedtek, és arra irányulnak, hogy ha az illető beteg nem szeretne újraélesztésben részesülni, azt jelzi (például egy ún. „DNACPR - Do not attempt cardiopulmonary resuscitation! [Ne végezz cardiopulmonalis resuscitatiót!] karpereccel). Különösen fontosak ezek a törekvések egy olyan időszakban, amikor az egészségügyi mentőszolgálat kapacitása túltelítődött, és a segítséget nyújtók megfertőződésének kockázata nem elhanyagolható $[5,10]$.

A járvány alatt a SARS-CoV-2 gyors terjedése miatt az elektív kórházi felvételeket megszüntették, hogy helyet tudjanak biztosítani a COVID-19-betegeknek. Ezt demonstrálja a kórházi felvételszám Németországban tapasztalt 23\%-os csökkenése. Annak ellenére, hogy a kórházi felvételek száma mérséklődött, a kórházon belüli szívmegállás előfordulása 11\%-kal emelkedett, amint az a 
Roedl és mtsai által írt vizsgálatból is kiderül [36]. Ennek hátterében különböző okok szerepelhetnek. Először is a COVID-19-ben szenvedőknek eleve magasabb a kockázatuk a kórházon belüli szívmegállásra a rapid progreszsziójú légzési elégtelenség miatt, ami azonnali kezelés nélkül hirtelen szívhalálhoz vezethet. Ugyanakkor a betegek klinikai állapota az intenzív osztályos felvételkor súlyosabb volt a járvány alatt az azt megelőző évhez képest. Noha korai intenzív osztályos felvételi stratégiát követtek, a betegek a lezárások miatt későn jutottak egészségügyi ellátáshoz [36].

Míg Vuhanban [33] és egy New York-i kórházban [34] a kórházon belüli szívmegállást szenvedett betegpopulációban szignifikánsan magasabb mortalitásról számoltak be a járvány alatt, addig a New York University Langone Health (Manhattan) kampuszán [35] és Németországban [36] nem találtak eltérést a járványt megelőző évhez képest. A különbség hátterében álló okok nem teljesen tisztázottak: a kórházon belüli szívmegállást megelőző klinikai állapot súlyossága, illetve intézményi eltérések mind szerepet játszhatnak. Németországban jelentősen nagyobb arányban történt kórházon belüli szívmegállás az intenzív osztályokon, ahol a magasabb arányú nővér/orvos személyzetnek és a folyamatos monitorozásnak köszönhetően gyorsan tudtak reagálni. Ezenkívül Roedl és mtsai kiválasztották azon, kórházon belüli szívmegálláson átesett betegeket, akik súlyos légzési elégtelenségben szenvedtek, majd megvizsgálták, hogy közülük hányan voltak igazoltan COVID-19-pozitívak. Az így kapott betegpopulációt összehasonlították azon, kórházon belüli szívmegállást szenvedett betegekkel, akiknél a légzési elégtelenség hátterében nem a COVID-19 állt (a pontos okokat nem tisztázták). Érdekes módon a COVID-19-pozitív betegpopulációban 58\%-ban volt kedvezőtlen neurológiai kimenetel, illetve halálozás, míg a nem COVID-os csoportban 90\%-ban. Az eltérés oka kérdéses, a COVID-19-betegek azonban kisebb arányban szenvedtek más társbetegségben [36].

\section{Következtetés}

A COVID-19-pandémia ideje alatt jelentősen megnövekedett a kórházon kívüli és belüli szívmegállás incidenciája, mely gyakran nagyobb mortalitással is együtt járt. A fertőzés közvetlen hatása mellett, a járványnak közvetett úton is szerepe lehetett ebben. A túlélési lánc megbomlása hozzájárulhatott a kedvezőtlen kimenetelhez. Mind a prehospitális, mind pedig a hospitális ellátás gyakorlatában jelentős változások történtek, ami magyarázhatja a világ különböző pontjain megfigyelt eltéréseket. Az ERC 2021. évi ajánlása azonban a fentiek kivételével érdemi változtatást nem javasolt a BLS-ben [44]. A kritikus „no-flow” időfaktorok emelkedését és így a beteg állapotának további súlyosbodását a COVID-19-pozitív/negatív infekciós triázs, illetve a szemtanú által és a korán megkezdett BLS hiánya miatt rangsorolási hátrányba kerülő, keringésmegállást elszenvedő betegek ellátása okozza.

Anyagi támogatás: A kutatás és a közlemény megírása anyagi támogatásban nem részesült.

Szerzői munkamegosztás: F.-Gy. A.: Irodalomkutatás, a kézirat összeállítása, a táblázatok elkészítése. K. E., K. B., Z. E.: A kézirat szakmai véleményezése, végleges formájának kialakítása, szerkesztése. A cikk végleges változatát valamennyi szerző elolvasta és jóváhagyta.

Érdekeltségek: A szerzőknek nincsenek érdekeltségeik.

\section{Irodalom}

[1] Wu Y, Ho W, Huang Y, et al. SARS-CoV-2 is an appropriate name for the new coronavirus. Lancet 2020; 395: 949-950.

[2] Zhou F, Yu T, Du R, et al. Clinical course and risk factors for mortality of adult inpatients with COVID-19 in Wuhan, China: a retrospective cohort study. Lancet 2020; 395: 1054-1062. [Erratum: Lancet 2020; 395: 1038.]

[3] World Health Organization. Coronavirus disease (COVID-19). Events as they happen. Rolling updates on Coronavirus (COVID-19). WHO, Geneva, updated: 31 July 2020. Available from: https://www.who.int/emergencies/diseases/novel-coronavirus-2019/events-as-they-happen [accessed: July 30, 2021].

[4] Marijon E, Karam N, Jost D, et al. Out-of-hospital cardiac arrest during the COVID-19 pandemic in Paris, France: a populationbased, observational study. Lancet Public Health 2020; 5: e437e443.

[5] Lim ZJ, Ponnapa Reddy M, Afroz A, et al. Incidence and outcome of out-of-hospital cardiac arrests in the COVID-19 era: a systematic review and meta-analysis. Resuscitation 2020; 157: $248-258$.

[6] Rosenbaum L. The untold toll. The pandemic's effects on patients without Covid-19. N Engl J Med. 2020; 382: 2368-2371

[7] Baldi E, Sechi GM, Mare C, al. Out-of-hospital cardiac arrest during the Covid-19 outbreak in Italy. N Engl J Med. 2020; 383: 496-498.

[8] Lai PH, Lancet EA, Weiden MD, et al. Characteristics associated with out-of-hospital cardiac arrests and resuscitations during the novel coronavirus disease 2019 pandemic in New York City. JAMA Cardiol. 2020; 5: 1154-1163.

[9] Bossaert LL. Fibrillation and defibrillation of the heart. Br J Anaesth. 1997; 79: 203-213.

[10] Scquizzato T, Landoni G, Paoli A, et al. Effects of COVID-19 pandemic on out-of-hospital cardiac arrest: a systematic review. Resuscitation 2020; 157: 241-247.

[11] Bonow RO, Fonarow GC, O'Gara PT, et al. Association of coronavirus disease 2019 (COVID-19) with myocardial injury and mortality. JAMA Cardiol. 2020; 5: 751-753.

[12] Ciceri F, Beretta L, Scandroglio AM, et al. Microvascular COVID-19 lung vessels obstructive thromboinflammatory syndrome (MicroCLOTS): an atypical acute respiratory distress syndrome working hypothesis. Crit Care Resusc. 2020; 22: 95-97.

[13] De Filippo O, D'Ascenzo F, Angelini F, et al. Reduced rate of hospital admissions for ACS during Covid-19 outbreak in Northern Italy. N Engl J Med. 2020; 383: 88-89.

[14] Larsen JM, Ravkilde J. Acute coronary angiography in patients resuscitated from out-of-hospital cardiac arrest - a systematic review and meta-analysis. Resuscitation 2012; 83: 1427-1433. 
[15] Scquizzato T, Olasveengen TM, Ristagno G, et al. The other side of novel coronavirus outbreak: fear of performing cardiopulmonary resuscitation. Resuscitation 2020; 150: 92-93.

[16] Semeraro F, Gamberini L, Tartaglione M, et al. An integrated response to the impact of coronavirus outbreak on the Emergency Medical Services of Emilia Romagna. Resuscitation 2020; 151: 1-2.

[17] Baldi E, Sechi GM, Mare C, et al. COVID-19 kills at home: the close relationship between the epidemic and the increase of outof-hospital cardiac arrests. Eur Heart J. 2020; 41: 3045-3054.

[18] Paoli A, Brischigliaro L, Scquizzato T, et al. Out-of-hospital cardiac arrest during the COVID-19 pandemic in the Province of Padua, Northeast Italy. Resuscitation 2020; 154: 47-49.

[19] Semeraro F, Gamberini L, Tartaglione M, et al. Out-of-hospital cardiac arrest during the COVID-19 era in Bologna: system response to preserve performances. Resuscitation 2020; 157: 1-2.

[20] Uy-Evanado A, Chugh HS, Sargsyan A, et al. Out-of-hospital cardiac arrest response and outcomes during the COVID-19 pandemic. JACC Clin Electrophysiol. 2021; 7: 6-11.

[21] Fothergill RT, Smith AL, Wrigley F, et al. Out-of-hospital cardiac arrest in London during the COVID-19 pandemic. Resusc Plus 2021; 5: 100066

[22] Sayre MR, Barnard LM, Counts CR, et al. Prevalence of COVID-19 in out-of- hospital cardiac arrest: implications for bystander cardiopulmonary resuscitation. Circulation 2020; 142: 507-509.

[23] Cho JW, Jung H, Lee MJ, et al. Preparedness of personal protective equipment and implementation of new CPR strategies for patients with out-of-hospital cardiac arrest in the COVID-19 era. Resusc Plus 2020; 3: 100015.

[24] Ball J, Nehme Z, Bernard S, et al. Collateral damage: Hidden impact of the COVID-19 pandemic on the out-of-hospital cardiac arrest system-of-care. Resuscitation 2020; 156: 157-163.

[25] Elmer J, Okubo M, Guyette FX, et al. Indirect effects of COVID-19 on OHCA in a low prevalence region. Resuscitation 2020; 156: 282-283.

[26] Rosell Ortiz F, Fernández del Valle P, Knox EC, et al. Influence of the Covid-19 pandemic on out-of-hospital cardiac arrest. A Spanish nationwide prospective cohort study. Resuscitation 2020; 157: 230-240.

[27] Andersen LW, Holmberg MJ, Berg KM, et al. In-hospital cardiac arrest: a review. JAMA 2019; 321: 1200-1210.

[28] Benjamin EJ, Muntner P, Alonso A, et al. Heart disease and stroke statistics - 2019 update: a report from the American Heart Association. Circulation 2019; 139: e56-e528.

[29] Sandroni C, Nolan J, Cavallaro F, et al. In-hospital cardiac arrest: incidence, prognosis and possible measures to improve survival. Intensive Care Med. 2007; 33: 237-245.

[30] Nolan JP, Soar J, Smith GB, et al. Incidence and outcome of inhospital cardiac arrest in the United Kingdom National Cardiac Arrest Audit. Resuscitation 2014; 85: 987-992.

[31] Efendijev I, Nurmi J, Castrén M, et al. Incidence and outcome from adult cardiac arrest occurring in the intensive care unit: a systematic review of the literature. Resuscitation 2014; 85: 472-479.

[32] Schluep M, Gravesteijn BY, Stolker RJ, et al. One-year survival after in-hospital cardiac arrest: a systematic review and metaanalysis. Resuscitation 2018; 132: 90-100.

[33] Shao F, Xu S, Ma X, et al. In-hospital cardiac arrest outcomes among patients with COVID-19 pneumonia in Wuhan, China. Resuscitation 2020; 151: 18-23.

[34] Sheth V, Chishti I, Rothman A, et al. Outcomes of in-hospital cardiac arrest in patients with COVID-19 in New York City. Resuscitation 2020; 155: 3-5.

[35] Yuriditsky E, Mitchell OJ, Brosnahan SB, et al. Clinical characteristics and outcomes of in-hospital cardiac arrest among patients with and without COVID-19. Resusc Plus 2020; 4: 100054.

[36] Roedl K, Söffker G, Fischer D, et al. Effects of COVID-19 on in-hospital cardiac arrest: incidence, causes, and outcome - a retrospective cohort study. Scand J Trauma Resusc Emerg Med. 2021; 29: 30.

[37] Fried JA, Ramasubbu K, Bhatt R, et al. The variety of cardiovascular presentations of COVID-19. Circulation 2020; 141: 1930-1936.

[38] Kulkarni P, Mahadevappa M. COVID-19 pandemic and the reduction in ST-elevation myocardial infarction admissions. Postgrad Med J. 2020; 96: 436-437.

[39] Negreira Caamaño M, Piqueras Flores J, Mateo Gómez C. Impact of COVID-19 pandemic in cardiology admissions. Med Clin (Engl Ed). 2020; 155: 179-180.

[40] Sahu AK, Suresh S, Mathew R, et al. Impact of personal protective equipment on the effectiveness of chest compression. A systematic review and meta-analysis. Am J Emerg Med. 2021; 39: 190-196

[41] Parush A, Wacht O, Gomes R, et al. Human factor considerations in using personal protective equipment in the COVID-19 pandemic context: binational survey study. J Med Internet Res. 2020; 22: e19947.

[42] Nolan JP, Monsieurs KG, Bossaert L, et al. European Resuscitation Council COVID-19 guidelines executive summary. Resuscitation $2020 ; 153$ : 45-55.

[43] Soar J, Lott C, Böttiger BW, et al. Advanced life support in adults. European Resuscitation Council COVID-19 guidelines. Section 3. 24 April 2020; pp. 9-12.

[44] Perkins GD, Gräsner JT, Semeraro F, et al. European Resuscitation Council Guidelines 2021: executive summary. Resuscitation 2021; 161: 1-60. [Erratum: Resuscitation 2021; 163: 97-98.]

(Zima Endre István dr., Budapest, Városmajor u. 68., 1122 e-mail: zima.endre@gmail.com)

A cikk a Creative Commons Attribution 4.0 International License (https://creativecommons.org/licenses/by/4.0/) feltételei szerint publikált Open Access közlemény, melynek szellemében a cikk bármilyen médiumban szabadon felhasználható, megosztható és újraközölhető, feltéve, hogy az eredeti szerző és a közlés helye, illetve a CC License linkje és az esetlegesen végrehajtott módosítások feltüntetésre kerülnek. (SID_1) 